\title{
Beyond Purity
}

\section{A Response To Sangster}

\section{Karen Dubinsky \& Lynne Marks}

Readers of left history may well have experienced a number of disorienting sensations: watching media coverage of a political event or demonstration one attended which completely distorts what one observed, or reading reviews of one's own book and finding it unrecognizable. Reading Joan Sangster's 'Beyond Dichotomies" had a bit of the same effect. Canadian women's history, and its relationship to the emerging field of gender history, as we have studied it, taught it, and written it is - from Sangster's presentation - barely recognizable. We suppose we are among the members of the "younger, more hip generation" (counterposed, presumably, to the sober socialist feminist), whose "consumer choice" Sangster decries. And so we welcome the opportunity to tell our version of the story.

Perhaps the most disappointing aspect of Sangster's polemic is the narrowness of her vision. Despite what we are going to say about the dreariness of our political conjuncture, we want to argue that this is actually a great time for feminist history. By feminist history we include much (but certainly not all) of what has been written by women's historians, gender historians, and indeed any historians who incorporate a concern with and analysis of issues of gender and other forms of power and oppression within their work. 
Far from drowning under the dead weight of post-structuralism and gender analysis, as Sangster implies, we think that these days feminists are carving out fascinating new topics and re-invigorating old ones. Take a quick look, for example, at the dusty old topic of British imperialism, a masculine bastion if there ever was one. Yet recently the field has been electrified by writings probing the links between race, gender, sexuality, and empire. These works have excavated a host of new historical actors (many of them previously overlooked females) and establish that women and men experienced imperialism in different ways, both central tasks of women's history. But they have also shown how gender power was a central feature of the project of imperialism. As Anne McClintock has argued in Imperial Leather,

Gender power was not the superficial patina of empire, an ephemeral gloss over the more decisive mechanics of class or race. Rather gender dynamics were, from the outset, fundamental to the securing and maintenance of the imperial enterprise. ${ }^{1}$

McClintock's work is one example of the current multi-faceted, interdisciplinary feminist historical scholarship which defies rigid categorization. It is delightfully, and effectively, non-sectarian in its theoretical approach, influenced by historical materialism and post-structuralism, psychoanalytic theories and feminism, theories of race, class and gender.

Linda Gordon's new book on the history of the American welfare state also illustrates the sophistication of analysis which can be achieved when historians take seriously the notion of gender

1 Anne McClintock, Imperial Leather: Race, Gender and Sexuality in the Colonial Contest (New York 1995), 7. See also Antionette Burton, Borders of History: British Feminists, Indian Women and Imperial Culture, 1856-1915 (Chapel Hill 1994); Nuper Chaudhuri and Margaret Strobel, eds., Western Women and Imperialism: Complicity and Resistance (Bloomington 1992), Annie E. Coombes, Reinventing Africa: Museums, Material Culture and Popular Imagination in Late Victorian and Edwardian England (New Haven 1994), and Mary Louise Pratt, Imperial Eyes: Travel Writing and Transculturation (New York 1992). 
as an analytic, as well as descriptive, category. By incorporating gender into the story of the welfare state, Gordon has both excavated the history of women - poor single mothers and welfare reformers - and challenged historians, political scientists and other writers on state policies to consider how gender ideals, values and norms have become entrenched in the social policies of American life. Furthermore, her subtle contrast between 'social insurance' (largely masculinist) and 'social work' (largely female, sometimes feminist) visions of welfare provides valuable and nuanced ways to think about gender. The story of different visions of welfare, she suggests, should remind us that gender is not a "universal, eternal opposition of male and female", but rather "a set of social norms about the meanings of femaleness and maleness and ... the division of labour; contextual and historically changing; norms that work jointly with many other aspects of individual and group identity and experience.",2

These and other works show the value of integrating the insights of both gender history and women's history. ${ }^{3}$ The dichotomies Sangster wants us to move beyond are those of her own creation. There is no need to choose between these two fields, any more than we should choose between race, class and gender (or, for that matter, socialism and feminism). Gender history, as we see it, is closely linked to women's history - it neither supercedes it nor renders it obsolete.

2 Linda Gordon, Pitied But Not Entitled: Single Mothers and the History of Welfare 1890-1935 (New York 1994), 290.

3 Also see, for example, Anna Clark, The Struggle For The Breeches: Gender and the Making of the British Working Class (Berkeley, California 1995); Teresa Anne Murphy, Ten Hours Labor: Religion, Reform and Gender in Early New England (Ithaca, N.Y. 1992) and Mariana Valverde, "Comment" in "Gender History/Women's History: Is Feminist Scholarship Losing Its Critical Edge?" Journal of Women's History, 5, 1 (Spring 1993). In the Canadian context, Valerie Korinek's, "No Women Need Apply: The Ordination of Women in the United Church," Canadian Historical Review (Dec. 1993) shows clearly how a gender history analysis of how the Christian ministry was constructed in masculine terms can shed new light on a longstanding topic in women's history. 
On the contrary, contemporary feminist historiography is realizing the early promises and hopes of women's historians. "The task that lies ahead," declared the editors of the 1974 anthology, Women at Work, 1850-1930 (one of the first women's history books published in Canada) "encompasses a re-evaluation not only of our own history but of the history of the relations between the sexes."4 Almost a decade later, women's history was lodged precariously within academia, where two of its pracitioners, Ruth Pierson and Alison Prentice, made the same argument, noting that "a full understanding of what has happened historically to males, in any field, at any time, simply cannot be gained without equal consideration of the impact of those developments on the females in that society - the reverse, of course, being also true." Another decade later, as we attend academic conferences, peruse historical journals, and hear about the research interests of graduate students, we see lots of interesting feminist historical work which takes women as its subject and starting point. We also see lots of other interesting feminist work which takes state policy, gambling, department stores, insanity, tourism, teenagers and men as its subject, while remaining sensitive to issues of gender, power and oppression. We do not see such diversification as a weakness, but rather as a testament to the strength of feminist historical analysis. We are (to borrow the language of another liberation movement) everywhere. Or at least our analysis is. Isn't this what the project was all about?

Sangster suggests that our generation have not behaved as respectful, dutiful daughters. We find her use of a generational division perplexing here since, although she focuses on a critique of the work of our generation, she acknowledges that more senior scholars have been among the leading proponents of gender history 1974), 9.

5 Ruth Pierson and Alison Prentice, "Feminism and the Writing and Teaching of History," in Angela Miles and Geraldine Finn, eds., Feminism in Canada: From Pressure to Politics (Montreal 1982), 113. 
and post-structuralist theory. ${ }^{6}$ We do not believe that we (or our more senior gender history colleagues) have been as dismissive of the work of feminist scholars who have gone before us as Sangster asserts. However, we do argue that Sangster exhibits an overly narrow vision of feminist history in Canada. We want to challenge this vision by addressing two main topics: her concerns about gender analysis and the history of masculinity, and her creation of unfortunate (and non-existent) dichotomies and polarities.

We see one of these dichotomies - or divisions - as particularly troubling. Playing the game of good $v s$. bad feminist is an old but ever popular pastime - but it produces no real winners. This dichotomy appears within another dichotomy which Sangster creates over the way women's historians/gender historians have understood questions of difference between women. She makes a clear distinction between what she defines as a bad poststructuralist gender history approach which, as she sees it, "hedges" by talking about multiple and intersecting identities that include not only gender, class and race, but also other categories of identity, such as age, religion and marital status - and the one true socialist feminist way of understanding difference and power. ${ }^{7}$ This approach assumes that we know the only real sources of oppression and identity, and that they are the "holy trinity" of gender, class, and race. For Sangster this particular dichotomy contains within it a number of other dichotomies - between "good" socialist feminist theory and "bad" post-structuralist theory and, more subtly, between good, grounded, empirical work that focuses on women's experience, and bad, elitist, theoretical post-structural work that ignores women's material experiences and focuses on more "personal" (read less significant) issues of identity. ${ }^{8}$ We are not denying

6 See, for example, Joy Parr, The Gender of Breadwinners: Women, Men and Change in Two Industrial Towns, 1880-1959 (Toronto 1990) and Ruth Pierson, "Gender and the Unemployment Insurance Debates in Canada," Labour/Le Travail, 25 (Spring 1990).

7 Joan Sangster, "Beyond Dichotomies: Re-Assessing Gender History and Women's History in Canada," left history, 3.1 (Spring/Summer 1995), 113.

8 Sangster, "Beyond Dichotomies," 114. 
that there can at times be some truth in Sangster's critique of post-structuralism. But we would argue that in identifying such differences between women's history and gender history, she paints with a rather broad brush, for example, in providing a stark contrast between the Foucaultian analysis of Carolyn Strange and the class analysis of Alice Klein and Wayne Roberts (a distinction which ignores the significance of class to Strange's work). As well as ignoring the many commonalities between the two "camps" at least in the Canadian context - Sangster also fails to recognize the fact that the dichotomies she sets up do not always work in the ways she suggests. We would certainly agree that gender, race, and class are key axes of oppression, and thus central both to individual identity, and group consciousness. However, we would go on to add that to focus exclusively on these categories does in some contexts do damage to the way life was actually lived and experienced by women and men in the past. Indeed, one of us began her study of religion and leisure with an exclusive focus on gender and class, but found that the realities of small town Ontario life forced her to confront the importance of age and marital status as well. ${ }^{9}$ Attention to historical context then, more than any commitment to post-structuralism, led to the "hedging" that so irritates Sangster. (Indeed the accusation that this particular gender historian was part of the post-structuralist camp convulsed her truly post-structurally hip graduate students.)

We would hardly deny that class, race, and gender are central axes of oppression. We are arguing, however, that in particular contexts other forms of power can also be significant. Certainly socialist feminism itself has shifted its position on "the" central categories of oppression. Starting with an insistence that gender and class were key, race, and more reluctantly sexual orientation, have been added to the pantheon. It is not selling out to recognize that in certain contexts other forms of power and inequality - such

9 Lynne Marks, Revivals and Roller Rinks: Religion, Leisure and Identity in Late-Nineteenth-Century Small Town Ontario (Toronto forthcoming). 
as those based on age or religion - were also experienced as central. To look for the issues that may have been key in particular times and places is more useful - as well as more respectful of women's experience - than approaching historical sources with pre-determined answers.

A central concern of socialist feminist historians has been with questions of women's consciousness - of the way women see themselves, and define themselves in the world. ${ }^{10}$ These concerns are certainly not far removed from those questions of identity that Sangster dismisses as the diversionary interests of post-structuralists. As Joy Parr has recently shown, an understanding of identity requires a willingness to refrain from imposing one category - be it class or gender - on historical actors, and to recognize instead the complexity and diversity of the range of categories that can be part of identity or consciousness in particular historical contexts. ${ }^{11}$

A reluctance to accept complexity and diversity within the feminist history project is evident in other facets of Sangster's article. Among the most puzzling implications of her argument is her suggestion that gender history and the study of masculinity will blunt our political, feminist edge. She acknowledges that she is not the first to make this argument. Judith Bennett, for example, has argued that the study of gender advocated by Joan Scott "intellectualizes and abstracts the inequality of the sexes," for it overlooks the "hard lives of women in the past."12 The problem here is that this conflates two arguments into one. This argument against gender history involves both the historian (the feminist presence in the university) and the history we write (the subject of our study). While in important and obvious respects these two are related, they are not the same.

10 See, for example, Nancy Hewitt, Women's Activism and Social Change: Rochester, New York, 1822-1872 (Ithaca 1984) and Christine Stansell, City of Women: Sex and Class in New York, 1789-1860 (Urbana 1987).

11 Parr, Gender of Breadwinners and Joy Parr, "Gender History and Historical Practice," Canadian Historical Review, 76, 3 (Sept. 1995).

12 Judith Bennett, "Feminism and History," Gender and History, 1, 3 (Fall 1989) 258. 
The concern that our political edge has been blunted by gender history is based on a scarcity model. It presumes that the supply of feminist historians is limited, and that we occupy shaky, unpopular ground within the academic hierarchy. Within the discipline of history, our attempt to tell the story of Canadian women's past is still woefully incomplete, and if we don't study women, surely no one else is going to. This is all true enough. Yet without advancing a Whiggish progress narrative, there are other ways of telling this story, and hence other models upon which we might base a political analysis. We think it's important to recognize that the situation in universities, for women and for feminists, has changed in recent years. We are not simply a powerless minority, who must all hew to a common "line" to further the cause of Canadian womanhood, past and present. Our changing situation makes it more possible to be open to new approaches - while we would argue that the many challenges that remain make it imperative that we do so.

We highlight the 'up side,' because it forces us to remember that in certain contexts, feminist historians can hardly be characterized as powerless. To begin with, some of us have relatively secure, meaningful, paid employment, which affords us a great degree of autonomy. Let's not kid ourselves about the luxury of this in the mid-1990s. Furthermore, when we grade our students work, judge their applications for admission and/or graduate funding, ask our secretaries or our research assistants to do our photocopying for us, sit on a funding or prize jury, read manuscripts for journals or publishers, decide whether or not to accept a student's story regarding a late essay, we are indeed exercising power. That like our female students, we also experience the reality of male power in the workplace on a daily basis does not diminish this. As we have long tried to remind men, people who are unaware of their own power in personal relations, or people who hold only an abstract notion of power ("men" or "the ruling class") which excludes themselves, often abuse it.

While the very existence of this debate suggests that women and feminists have indeed made some headway in the institutions of academia, the existence of other debates - witness the Globe and 
Mail inspired moral panic about feminists taking over Canadian political science departments - shows that rumours of our life are very much exaggerated. As we see it, what's vexing and complicated about the position of feminists within academia at present is that we - speaking of individual feminists and feminist analysis in general - have much less power or influence than is popularly assumed, but more power and influence than was the case when the project began several decades ago. We are among the first generation of students who could specialize in women's history 'legitimately' within our institutions - an enormous privilege. So we benefitted from the hard work of the second wave, and arrived just in time for the anti-feminist backlash and funding crisis. We can only speculate at the toll that will be taken on both women and feminist scholarship as governments scale back their commitment to post-secondary education, and we shudder at the bleak future for those students and others without an even vaguely secure niche in the system already. That there may not be uppity young graduate students with the resources to develop their own critique of our generation's work is a privilege we would be happy not to have. That the current generation of graduate students includes a handful of people of colour, many of whom are engaged in a sustained analysis of the history of race and ethnicity in Canada, makes the uncertain future of academic endeavours in this country even more intolerable.

How is writing about the history of gender going to make this worse? How will gender history contribute to the further decline or marginalization of women and/or feminists within the university? We just don't see it. It's not writing about gender that is the problem here; it's the political economy, power relations and white male domination of the university. In fact we would argue that writing about men as gendered, historical actors can actually strengthen our feminist critique - deepening and broadening the focus of our political analysis. Bad history - by which we mean analyses which ignore power relations - can be written about men, but such history can and indeed is also being written about women, peasants, workers, the rulers, and the ruled. 
There is indeed some bad history being written about men. Consider, for example, Anthony Rotundo's overview of two centuries of American middle-class manhood, which, while in many ways a useful exploration of the male side of the separate spheres divide, is unforgivably silent on the question of men's physical power over women, and flirts with the possibility that there is a biological basis for the aggressive culture of nineteenth-century boyhood. ${ }^{13}$ Yet Rotundo's problem is not his topic, for contrast this to the portrait of middle-class masculinity drawn by Davidoff and Hall in the English context, which is rooted in the premise that the power of middle-class men was a contested, socially created process. ${ }^{14}$ (Though it too, we would argue, is too quiet about how this process was achieved both by consent and coercion).

In our view, the best of the recent work on the history of masculinity starts from the premise, outlined by Michael Roper and John Tosh, that masculinity is a relational concept, formed "in relationship to men's social power," particularly their power over women. ${ }^{15}$ Here Sangster's (footnoteless) assertion that she finds "few studies of masculinity making the ... claim that women must be integrated into their analysis; instead, masculinity it is presumed, can stand on its own," is overstated. ${ }^{16}$ Some historians of masculinity frame their story from a feminist perspective which foregrounds male power, some do not. ${ }^{17}$ But this is no different, and

13 Anthony E. Rotundo, American Manhood: Transformations in Masculinity from the Revolution to the Modern Era (New York 1993) and Rotundo, "Boy Culture: Middle-Class Boyhood in Nineteenth Century America," in Mark C. Carnes and Clyde Griffen, eds., Meanings for Manhood: Constructions of Masculinity in Victorian America (Chicago 1990).

14 Leonore Davidoff and Catherine Hall, Family Fortunes: Men and Women of the English Middle Class, 1780-1850 (London 1987).

15 Michael Roper and John Tosh, "Historians and the Politics of Masculinity," in Michael Roper and John Tosh, eds., Manful Assertions: Masculinities in Britain Since 1800 (London and New York 1991), 2.

16 Sangster, "Beyond Dichotomies," 119.

17 For an examination of how the changing intersections of masculinity and femininity in evangelical discourse could have very real implications in shaping men's power and authority over women's lives see Susan Juster, Disorderly Women: Sexual Politics and Evangelicalism in Revolutionary 
no less problematic, than the fact that some historians of women have failed to grasp what should be an equally important premise of feminist history: that white women's identities historically have been formed in relationship to their power over other races and ethnic groups. ${ }^{18}$ Sangster is much more ready to critique the emerging field of the history of masculinity than to address the limitations that remain evident within Canadian women's history. While Canadian feminist activists and academics have wrestled with the topic of racial and ethnic relations between women for over a decade, Canadian women's history lags seriously behind on this topic. It is true that gender historians have not "discovered" race, and some fine studies of women from non-European racial groups exist within Canadian women's history. Nonetheless, the poststructuralist insight that racial meanings are integral to understanding all groups of women remains largely ignored. For example, almost no one in the country has attempted to re-write the history of Canadian feminism (a project which is ongoing in several other national contexts) with a race-conscious analysis. Some Canadian women's historians seem content to simply ignore these questions, claiming Nellie McClung, for example, as an unproblematic feminist ally because her participation in the social purity movement helped to "save young women from sexual exploita-

New England (Ithaca, N.Y. 1994). In Constructing Brotherhood: Class, Gender and Fraternalism (Princeton, 1989) Mary Ann Clawson shows clearly how nineteenth century fraternal orders, defined in masculine terms, served to exclude and marginalize women. For a range of recent work on the history of masculinity, particularly in relation to sexuality, see Lesley Hall, Hidden Anxieties: Male Sexuality, 1900-1950 (London 1990); Jonathan Katz, The Invention of Heterosexuality (New York 1995); Kevin White, The First Sexual Revolution: The Emergence of Male Heterosexuality in Modern America (New York 1993); Angus McLaren, A Prescription for Murder: The Victorian Serial Killings of Dr. Thomas Neill Cream (Chicago 1993) and George Chauncey, Gay New York (New York 1994).

18 See, for example, Antoinette Burton, Burdens of History: British Feminists, Indian Women and Imperial Culture, 1865-1915 (Chapel Hill 1994) and Vron Ware, Beyond the Pale: White Women, Racism and History (London 1992). 
tion," ignoring the class- and race-based assumptions imbedded in much social purity work, which often simply served to further control the lives of the young women being "saved."19

Sangster may argue that a critique of the racism of first wave white feminists is nothing new, having been undertaken by Bacchi thirteen years ago. We differ here, believing that we need further work that moves us beyond Bacchi's simplistic blaming of "bad" feminist foremothers for not sharing our politics, towards a sensitive understanding of how race shaped these women's world view and claims on social power.

The problem here then is not with the topic - whether it be men or first wave feminists - it's with the analysis of the topic. It's not that there's been too much attention paid to Anglo women in Canadian history, but rather that racial and ethnic power has not been written into the story of Canadian feminism, Canadian women, and Canadian society. 'Racing' whiteness is not so very different from 'gendering' men: both projects seek to make the universal particular, and examine how, historically, the particular became defined as universal and therefore, powerful.

Who needs more histories of men? This question, posed by both Sangster and Judith Bennet, evokes the perennial question of children on Mother's and Father's Day. "Why is there no Children's Day?" the children ask. "Every day is Children's Day," the parents wearily respond. Some might consider that every day is the history of masculinity; every course except for the tiny bits of territory carved out (after bitter battles) by feminist historians, every book in the library except our coveted shelf in the HQ section,

19 Randi Warne, "Introduction" in Nellie McClung, Purple Springs (Toronto 1992), xx. See Mariana Valverde, The Age of Light, Soap and Water (Toronto 1991) and Carolyn Strange, Toronto's Girl Problem (Toronto 1995) for recent efforts to recognize such issues. For other work in Canadian women's history which ignores class and race as categories see, for example, many of the articles in Elizabeth Gillan Muir and Marilyn Fardig Whiteley, eds., Changing Roles of Women Within the Christian Church in Canada (Toronto 1995). 
every research grant, every academic job except the token feminist one (or in some advanced and progressive departments, two).

But good, critical, feminist work on the history of masculinity will not contribute to masculine hegemony, it will help to undermine it. It will undermine it because it answers one of the masculinist dodges which every feminist historian will recognize: "I don't have to understand women because I study ..." the military, male trade unionists, politicians; in other words, anything which has been defined as 'not women,' and therefore 'not gender.' This argument is not simply about historical turf - you study women, I study not-women (everything else). It is also about power, for the relative invisibility of masculinity has historically been a key component of patriarchal hegemony. "Men," as John Tosh has elaborated, "were the norm against which women and children should be measured ... Women were "carriers' of gender," and masculinity "remained largely out of sight." ${ }^{20}$ Like middle-class people, heterosexual people and white people, masculinity is "everywhere and nowhere," in Tosh's words, which is why problematizing these categories is so important. In this respect, Sangster's comment that she finds "few people demanding that working-class history cannot be taught anymore unless we simultaneously teach middle-class or ruling class history along with it," again reveals the narrowness of her vision, for that is exactly what people like Davidoff and Hall have argued. Middle-class invisibility and 'normality' is indeed being studied, not to celebrate it but to understand how it attained hegemonic, and therefore invisible, unproblematic, status.

So, if we understand gender as a category of description (which has generally meant describing the activities of women, but could also mean the activities of gendered men), as well as a category of analysis, the apparently gender-neutral ground of 'the rest of his-

20 John Tosh, "What Should Historians do with Masculinity? Reflections on Nineteenth-century Britain," History Workshop Journal, 38 (1994), 180. 
tory' folds like a cheap suit. As Ava Baron has argued, (and as she, and many others, have also demonstrated in their empirical work)

The absence of women has often been used as a justification for bracketing gender when dealing with male-dominated unions and workplaces or when addressing issues such as class formation or the transformation of industrial capitalism ... But gender is present even when women are not. ${ }^{21}$

Far from seeing gender history as a retreat for feminism, we could argue (only half in jest) that it is one of the most brazenly imperialist moves feminism has ever made. If gender analysis is key to understanding women, men, and power in the past, that leaves very few stones unturned.

In defending gender history, and the post-structuralist theory used by many of its practitioners, we do recognize that there are dangers with this approach - as with the exclusive use of any theoretical approach. We do not want to focus only on how categories of meaning - whether of gender, race, class, or anything else - were constructed in particular historical contexts. This can, at its worst, become a theoretically fascinating but ultimately apolitical game. Categories must not simply be deconstructed - efforts must also be made to understand how they were experienced by women and men of the time. As well, for Anna Clark, as for other feminist scholars concerned with issues of oppression, the problem has been "how to link the elegant postmodernist play with language to the

21 Ava Baron, "On Looking at Men: Masculinity and the Making of a Gendered Working-Class History," in Ann-Louise Shapiro, ed., Feminists Revision History (New Brunswick 1994), 148. For recent Canadian work which points to the rewards of a gender history approach to studying male workers, both in the workplace and beyond see, for example, Nancy Forestell, "All that Glitters is not Gold': The Gender Dimensions of Work, Family and Community Life in the Northern Ontario Gold Mining Town of Timmins, 1909-1950" (Ph.D. thesis, OISE, University of Toronto, 1993); Suzanne Morton, Ideal Surroundings: Domestic Life in a Working-Class Suburb in the 1920s (Toronto 1995) and Mark Rosenfeld, "'She Was A Hard Life': Work, Family, Community, Politics and Ideology in the Railway Ward of a Central Ontario Town, 1900-1960," (Ph.D. thesis, York University, 1990). 
grubby historical questions of power." 22 Increasing numbers of historians (including Sangster herself, in another context) see the need to choose here between discourse or materialist analysis as a false dichotomy, and argue for the possibility of integrating both approaches. $^{23}$

If we can avoid its potential problems, we believe that the political possibilities of post-structuralist gender history are exciting indeed. We relish the opportunity to pose new challenges to those male political historians who have been decrying the fragmentation of Canadian history supposedly brought about by social and women's historians. ${ }^{24}$ Many "political" subjects could certainly benefit from a discourse analysis which focuses on issues of race, class, and gender - some have already found their historians, while others await study. In the current climate, examining the shifting use of gendered metaphors in the national unity debates can provide useful insights, while an exploration of the racial, class and sexual anxieties underlying nineteenth and early twentieth-century anti-Catholicism would deepen our understanding of a central facet of our political culture. Similarly, a study of the gendered meanings and sexual fears associated with anti-Asian sentiment and Canadian racism more generally has much to offer us in understanding issues that are still very much with us. The history of our rapidly

22 Anna Clark, "Comment," in "Gender History/Women's History," Journal of Women's History (Spring 1993).

23 Joan Sangster, Earning Respect: The Lives of Working Women in Small Town Ontario, 1920-1960 (Toronto 1995), 8-10; Ava Baron, 'Gender and Labor History,' in Baron, ed., Work Engendered: Toward a New History of American Labor (Ithaca and London 1991), 31; Ellen Ross, Love and Toil: Motherhood in Outcast London, 1870-1918 (New York and Oxford 1993), 9-10; Carolyn Strange, Toronto's Girl Problem (Toronto 1995), 12.

24 See Michael Bliss, "Privatizing the Mind: The Sundering of Canadian History, the Sundering of Canada," Journal of Canadian Studies, 26, 4 (Winter 1991-92). 
unravelling social safety net can only be fully understood in relation to the familial metaphors and gendered assumptions built into it. ${ }^{25}$

Perhaps we have wandered too far away from Sangster's article. But we do feel that asserting the potential of new ideas - like post-structuralism - in challenging those who would dismiss the legitimacy of gender, women's history and all so-called "ideological history" is more useful than attacking those engaged in a common project. We don't seek to stifle debate - we welcome it as long overdue within the small feminist history community in this country. But creating stark and overdrawn dichotomies, both politically and historically, is not a useful way to proceed.

We would like to thank our friends and colleagues who commented on an earlier draft of this paper. We, of course, take full responsibility for the final product.

25 See for example, Gail Cuthbert Brant, "National Unity and the Politics of Political History," Journal of the Canadian Historical Association (1992); J.R. Miller, "Anti-Catholic Thought in Victorian Canada," Canadian Historical Review, LXVI 4 (December 1985); Annalee Golz, "Family Matters: The Canadian Family and the State in the Postwar Period," left history, 1.2 (Fall 1993); Pierson, "Gender and the Unemployment Insurance Debates in Canada"; Maureen McCarthy, "The Rescue of True Womanhood: Convents and anti-Catholicism in 1830s America" (Ph.D. thesis, Rutgers University, 1996); Kay Anderson, Vancouver's Chinatown: Racial Discourse in Canada, 1875-1980 (Montreal 1991). 